\title{
DEVELOPMENT OF INTEGRATED SCIENCE LEARNING DEVICES USING PROBLEM BASED LEARNING (PBL) LEARNING MODEL THROUGH LESSON STUDY
}

\author{
Sarlota Singerin*, Estevanus.K.Huliselan, and Altje Latununuwe \\ Faculty of Education and Teacher Training, Pattimura University. \\ *email: singerin@yahoo.co.id
}

\begin{abstract}
The study was conducted at SMP Negeri 2 Salahutu. The purpose of this study is to develop a science learning tool using the Problem Based Learning learning model, through lesson study. The research design uses the $4 \mathrm{D}$ Research and Development research method (Define Phase, design, develop, Disseminate). The application of products in the form of PBLbased integrated science-oriented learning modules through LS results in the following findings: 1). The Global warming theme module is based on curriculum analysis, student and teacher needs and field observations; 2). The Global warming theme module is able to get students actively involved in the learning process. 3). PBL-based Global warming theme modules through Lesson Study train students' creativity; 4). The teacher's knowledge about the systematic writing of the modules is still lacking so that the writer at the time of dissemination gave a presentation on the systematic module. The results of this study found that 1). Development of Integrated Science Learning Using Models of Problem Based Learning through Lesson Study can improve the student learning outcomes; 2). Development of Integrated Science Learning based on Problem Base Learning through Lesson study using the Global warming theme module is based on curriculum analysis, student and teacher needs and field observations. This module is able to make students actively involved directly in the learning process and train students' creativity.
\end{abstract}

Keywords: Integrated Science Learning Tools, Problem Base Learning, Lesson Study

\section{Introduction}

Integrated science learning is one of the curriculum implementation models that is recommended to be applied at the basic education level, namely elementary and junior high schools. The implementation of integrated science learning requires adequate teacher professionalism. The teacher must have enough knowledge in conveying knowledge. IPA as a whole. In addition, in the delivery of science in an integrated manner required a form of learning models and appropriate learning tools. Lesson study can be used as a method for teachers to exchange ideas in the preparation and development of integrated science learning plans. According to Sudrajat (2008), lesson study is one of the efforts to improve the process and learning outcomes that are carried out collaboratively and continuously by a group of teachers.

Lesson study needs to be done in Indonesia, because efforts to improve the quality of education that have been carried out by the government through various teacher training programs, are generally limited to increasing understanding of subject matter, while the introduction of learning methods is carried out separately from subject matter. This makes it difficult for teachers to integrate. Lesson study which is applied as a model of student guidance for prospective teachers is proven to be able to improve the ability of students in implementing learning strategies (Rustono, 2007). Through three stages in the lesson study, namely planning (plan), implementation (do) and reflection (see ), teachers who collaborate on the preparation of learning plans can exchange ideas to get solutions to problems encountered. 
The development of integrated science learning is collaborated with the problem based learning model or Problem Base Learning (PBL). In the problem-based learning model, learning is carried out by presenting a problem to students, and students are asked to solve the problem. Solution to a problem related to science is done through a scientific method. Implementation of this scientific method requires students to do a scientific work, so that problem-based learning provides opportunities for students to be able to improve their scientific work skills. PBL learning model is a way of presenting learning material by making problems as a starting point for discussion of problems to be analyzed and synthesized in an effort to find solutions or answers by students. Problems can be raised or given by the teacher to students, from students with the teacher, or from students themselves, which are then used as discussions and solutions are sought as student learning activities. Thus, Problem Based Learning (Problem Based Learning) is a learning model that focuses on tracking the root of the problem and solving the problem (Abbudin, 2011: 243).

Based on the description stated in the background of the problem, the main problems in this study are: 1) How to develop integrated science learning through lesson study? 2) Whether integrated science learning that is collaborated with the Problem Base Learning model can improve scientific work skills and student learning outcomes. Based on the above problem formulation, the objectives to be achieved in this study are: 1) to obtain an integrated science learning model with the most appropriate problem-based learning through lessons, so as to improve students' scientific work. 2) find out the effectiveness of the integrated science learning model that is collaborated with the Problem Base Learning model in improving scientific work skills and student learning outcomes.

Lesson study is an activity carried out by the teacher working together to plan activities to improve the quality of learning undertaken by the teacher and student learning activities, and will make the teacher professional with good implementation design (Mustikasari, 2008). The three main parts of the lesson study are the first part, namely the identification of research themes (research themes), the second part is the implementation of a number of research lessons that will explore a research theme, and the third part is a reflection of the process of implementing lesson study.

Natural science or science is the study of natural phenomena which includes living and non-living creatures or the science of life and science about the physical world. Science knowledge is acquired and developed based on a series of research conducted by scientists in searching for answers to the questions "what?", "Why?", And "how?" From natural phenomena and their application in technology and everyday life. Science education emphasizes the provision of direct experience to develop competencies so that students are able to explore and understand the natural environment scientifically. Science education is directed to find out and do something so that it can help students to gain a deeper understanding of the natural surroundings. Therefore, the approach adopted in presenting science learning is to combine experience with the science process and understanding of science products in the form of direct experience (Depdiknas, 2002).

Scientific work is the steps of the scientific method carried out by scientists in finding solutions to a problem. Starting with a problem, scientists will look for solutions to problems based on theory, hypothesis and systematics. In finding solutions, it is done by making observations, then compiling hypotheses from the results of these observations, and testing hypotheses by conducting experiments to obtain data. The data will be processed and conclusions obtained which then the conclusions are tested again by repeated experiments by showing the same results proving that the conclusions made are correct, so that the truth can be accepted and can be considered as a theory or law.

Science learning in schools can apply scientific methods by getting students used to doing scientific work. Facing students to a problem to find a solution, can motivate students to do scientific work by applying scientific methods. The formulation of scientific methods, among others, make observations or observations of the surrounding 
environment, formulate the problem from the results of observations, formulate a hypothesis that is a temporary answer to the problem at hand, then design an experiment to test the hypothesis and carry out experimental design to obtain data, then the experimental data are analyzed and draws a conclusion from the hypothesis.

A conclusion that has been tested again by experimentation and shows the same results, can be called a theory or concept. The final step in the scientific method is to report the results of his scientific work as a whole starting from the formulation of the problem to the results of the experiments in the form of conclusions.

Integrated learning is an approach to teaching and learning that involves several fields of study to provide meaningful experiences for students. With integrated education, children will understand the concepts they learn through direct observation and connect with other concepts they understand. Integrated learning can begin with a particular subject or theme which is then linked to another subject through a good plan, thus creating a more meaningful learning. Integrated science learning is a science learning model that encompasses the whole science including biology, physics, chemistry. In integrated science learning, a theme is discussed from the point of view or study, both biology, physics and chemistry, so students can learn the whole science of a theme. The problem based learning model (Problem Base Learning) by John Dewey encourages teachers to involve students in various problem-oriented projects and help them investigate a problem. As for the characteristics of problem-based learning proposed by Arends (2008), there are stimulating questions or problems, problem-based learning organizes teaching around questions and problems that are important and meaningful for students. Learning focuses on interdisciplinary or interdisciplinary interrelationships, although based on a problem but can be centered on certain subjects such as science, mathematics, history or others. Authentic investigations, problem based learning, by means of students are required to carry out authentic investigations that try to find real solutions to real problems. Next, students analyze and establish problems, then develop hypotheses and make predictions, collect and analyze information, carry out experiments, make inferences and draw conclusions. Production of artifacts and exhibits, namely students are required to make certain products in the form of real work or demonstrations which are then demonstrated to other friends. Collaboration is applied to problem based learning which is characterized by the collaboration between students in groups or in pairs. Problem-based learning is designed to help students develop thinking skills, problem solving skills and intellectual skills and become independent learners.

Implementation of learning by using the Problem Base Learning model at least fulfills several characteristics, including in the learning process must begin with a problem; the content and implementation of learning must be able to attract the attention of students, the teacher only acts as a guide in the classroom, students are given time to think or find information to get answers to problems and in the learning process their creativity in thinking must be encouraged, creating comfortable learning situations and relaxed to develop students' ability to think and look for answers to problems independently (Akinoglu \& Tandogan, 2007).

\section{Research Method}

The type of research used is research and development education (Education Research and Development), which is developing integrated science learning with problem-based learning models through lesson study activities. This research was conducted through two stages, namely the pre-development stage and the development stage. The development phase is carried out through three trial processes to get products in the form of integrated science learning tools with a Problem Base Learning model that is ready to be used for science learning in junior high schools. The test subjects in this 
study were students of class VII as many as three classes in SMP Negeri 2 Salahutu in the even semester of the 2018/2019 school year.

Data collection techniques in this study include observing student activities, to determine student activity during the learning process; conduct tests to determine student learning outcomes; and reviewing the reflection sheet of lesson study activities to find out the improvement of learning tools developed. The data analysis technique used in this study was descriptive analysis to analyze the development of science learning and the results of observations of student activities, the results of student tests were analyzed using the one-way ANOVA test. The effectiveness of integrated science learning with PBL models on students' scientific work skills and student learning outcomes is analyzed by comparing the results of observations of scientific work skills and the average value of the three pilot classes.

\section{Results and Discussion}

The integrated science development research with the Problem Base Learning model through lesson study produced a learning tool consisting of a problem-based integrated science lesson plan made thematically with the theme "Global Warming", from which the theme was compiled the RPP for 3 meetings at each meeting carried out for 2 X 40 minutes. Each RPP raises one topic, RPP one raises the topic "global warming based on natural phenomena that occur in everyday life.", RPP two takes the theme "facts of global warming events", RPP three that raises the topic "causes of global warming and its impact on the ecosystem ".

Integrated Science Teaching Materials are made by discussing science materials including Biology, Physics and Chemistry in an integrated manner. Lesson study in the see phase produced some reflections submitted by lesson study team members which can be seen in Table 1. The results of observations on student activities related to scientific work skills at each stage of the trial showed an increase in scientific work skills and scientific attitudes of students. Table 2 shows the percentage of observations of scientific work skills from each pilot class. The percentage of the results of observations of scientific attitudes of each class of the trial can be seen in Table 3. The average student learning outcomes in the first, second and third try out classes show an increase that can be seen in Table 4 and Figure 1.

Based on the results of observations of scientific work skills of students participating in integrated science learning with the Problem Base Learning model shows an increase from first grade to third grade. The increase in scientific work skills is accompanied by an increase in learning achievement as indicated by the increasing average test scores in each class conducted after the learning process is carried out. Improving scientific work skills and student test results is evidence that the application of the Problem Base Learning learning model in learning Integrated junior secondary science developed through Lesson Study can be implemented effectively.

The use of the Problem Base Learning model in integrated science learning can create learning conditions that are centered on student activity so that students can construct their knowledge and can integrate lessons learned in school with everyday life (Akcay, 2009).

Giving a problem and the process of finding answers in learning can help students to more easily remember the material being studied, so students can better understand the material (Phee, 2002). In this study integrated science learning is carried out in a classical manner by raising the solvable problems associated with the theme of global warming through studies using the Problem Base Learning stage.

Research conducted by students is guided by the teacher, provides a direct experience for students to find their own causes of problems through a scientific work process that includes skills in making observations, formulating problems, formulating 
hypotheses, designing and conducting experiments, concluding the results of experiments, compiling reports and communicating it (MONE, 2002). Learning activities in the laboratory provide opportunities for students to use equipment and materials to be able to compile a knowledge of the phenomena found and relate them to existing scientific concepts (Hofstein \& Naaman, 2007). Through these activities students can independently find the answers to the problems given by the teacher and students can arrange their own knowledge, so that the knowledge gained will be stronger in students' memories. The Problem Base Learning model of learning is very supportive in improving students' scientific attitudes in implementing learning conducted by the inquiry method (Winanti, 2009). Improving scientific attitudes strongly supports the improvement of scientific work skills, the application of the Problem Base Learning model in integrated science learning also shows an increase in students' scientific work skills.

The development of integrated science learning with the Problem Base Learning model is done through lesson study activities which is one of the models of teacher professional training. The lesson study involved several science teachers and a team of science experts from the university. Lesson study begins with a workshop on teachers, aiming to introduce "what?", "Why?" And "how?" Lesson study is carried out. After that the lesson study team consisting of the teacher and the team of experts work together to carry out the stages in the lesson study (Karim, 2006). Lesson study activities carried out through three stages, namely the stages of plan, do and see (Susilo et al, 2009).

Lesson Study carried out by junior high school science teacher and expert team is very helpful for teachers in improving their abilities in preparing Learning Implementation Plans, worksheets, evaluation tools, teaching materials to the ability to deliver material in class. The lesson study team's observations during the trial process in class were then delivered in the see phase, helping the teacher to improve the learning tools that had been prepared. Improved learning tools greatly support the teacher's ability to create effective learning so students can learn in a scientific learning environment and be able to understand the material well, so that scientific ability and learning achievement can be improved. Lesson study activities aim to improve teacher professionalism through improving teaching methods and increasing knowledge (Cerbin \& Bryan, 2006). Observation of student learning activities, aims to determine the teaching methods or ways of teaching carried out by the teacher can learn students or not, so that the observation of students can be used to correct and improve the learning methods used.

Lesson study activities have a significant impact on teachers, this is evidenced by the increased ability of teachers who have participated in lesson study training activities in preparing lesson plans by applying relevant learning models, as well as being able to carry out learning based on the lesson plans that have been made, and after following training Teacher lesson study is able to guide other teachers in planning and implementing lesson study (Mulyana, 2008).

\section{Conclusion}

Based on the results of the study, it can be concluded that integrated science learning can be well developed through lesson study, through steps including: forming a lesson study team; do the pre-development stage, namely the stage of making learning model design; proceed to the development stage by testing the design of the learning model three times a trial and make improvements to the learning model in accordance with the results of reflection to get a learning model that is ready to use. Integrated science learning that is collaborated with the problem base learning model can improve students' scientific work skills and student learning outcomes effectively. 


\section{References}

Akcay, B. 2009. Problem base learning in science education. Journal of Turkish Education, 6 (1): 26-35

Akinoglu, O. \& Tandogan, R.O. 2007. The effects of problem based learning in science education on students academic achievement, attitude and concept learning. Eurasia journal of mathematics, science \& technology education, 3 (1): 71-81

Cerbin, W \& Kopp, B. 2006. Lesson Study a Model for Building Pedagogical Knowledge and Improving Teaching. International journal of teaching and learning in higher education, 18 (3): 250-257

Hofstein, A. \& Naaman, R.M. 2007. The laboratory in science education, the state of the art. Chemistry education research and practice, 8 (2): 105-107 Karim, M.A. 2006. Implementation of lesson studies for improving the quality of mathematics instruction in Malang. Tsukuba journal of educational studies in mathematics, 25: $67-73$

Mustikasari, A. 2008. Towards Professional Teachers Through Lesson Study. Semarang. http: // edu-articles. com / towards-the-teacher-professional-through-lesson-study /. September 3, 2008

Mulyana, S. 2008. The Impact of Education and Training on Study Lesson on Teachers. Research Result Articles. West Java LPMP

Phee, A.D.Mc. 2002. Problem base learning in initial teacher education: taking the agenda forward. Journal of education inquiry, 3 (1): 60-74

Rustono, E.H.M. Abdul Muin. 2007. Lesson Study as a Model Guidance for PGSD Students in the Field Experience Program in Elementary Schools. Coaching Research. UPI Education Faculty

Sudrajat, A. 2008. Lesson Study to Improve Learning Processes and Results. Now. http://akhmadsudrajat.wordpress.com/2008/02/22/lesson-study- to improve the process and learning-outcomes /. September 3, 2008

Susilo, H. et al. 2009. School-Based Lesson Study.Malang: Banyumedia Publishing

Winanti, S. 2009. Science-Based Learning Problem Through Guided Inquiry and Modified Free Inquiry in terms of Student's Scientific Attitudes and Creativity. (Thesis). Surakarta: Science Education Study Program Eleven March University Postgraduate Program 
Table 1. Reflections on Lesson Study Activities in Each RPP Implementation

\begin{tabular}{|c|c|c|c|}
\hline RPP & First class & Second Class & Third class \\
\hline $\begin{array}{l}\text { RPP I } \\
\text { (Global warming } \\
\text { based on natural } \\
\text { phenomena that } \\
\text { occur in daily life) }\end{array}$ & $\begin{array}{l}\text { 1. The learning process exceeds the time } \\
\text { limit } \\
\text { 2. } 40 \% \text { of students are able to observe } \\
\text { objects well } \\
\text { 3. } 60 \% \text { of students do not concentrate on } \\
\text { the lesson } \\
\text { 4. Only a few students actively answer } \\
\text { questions } \\
\text { 5. } 60 \% \text { of students do not complete the } \\
\text { worksheet }\end{array}$ & $\begin{array}{l}\text { 1. Learning can take place in accordance } \\
\text { with the available time } \\
\text { 2. Student observation ability is good } \\
\text { 3. Students are quite active in following } \\
\text { the lesson and only a small proportion } \\
\text { ignores the teacher's orders } \\
\text { 4. Students begin to dare to be open to the } \\
\text { teacher and other students, as seen from } \\
\text { the courage of some children to ask } \\
\text { questions to the teacher or to a group of } \\
\text { friends } \\
\text { 5. } 75 \% \text { of students work on the worksheet } \\
\text { completely }\end{array}$ & $\begin{array}{l}\text { 1. Learning takes place in accordance } \\
\text { with the available time } \\
\text { 2. Student observation skills are good } \\
\text { 3. } 95 \% \text { of students are active and } \\
\text { enthusiastic about learning } \\
\text { 4. } 80 \% \text { of students dare to ask } \\
\text { questions and answer teacher } \\
\text { questions } \\
\text { 5. 5. Most students work on worksheets } \\
\text { 6. completely }\end{array}$ \\
\hline $\begin{array}{l}\text { RPP } 2 \\
\text { (the fact of the } \\
\text { event of global } \\
\text { warming) }\end{array}$ & $\begin{array}{l}\text { 1. 50\% of students are not able to use } \\
\text { several tools properly such as a } \\
\text { thermometer, litmus and universal } \\
\text { indicators. } \\
\text { 2. 2. Some groups do not carry the } \\
\text { required tools (jars) } \\
\text { 3. In group work only } 1 \text { to } 2 \text { of } \\
\text { 4. } 6 \text { or } 7 \text { students who are active and dare } \\
\text { to try in practical activities } \\
\text { 5. Some children seem less serious about } \\
\text { practicing, instead playing alone } \\
\text { 6. } 60 \% \text { of students are deft in practicum } \\
\text { 7. } 60-65 \% \text { of students are less responsible }\end{array}$ & $\begin{array}{l}\text { 1. } 80 \% \text { siswa mampu mempergunakan } \\
\text { alat dengan baik seperti termometer, } \\
\text { lakmus dan indikator universal } \\
\text { 2. Tidak ada siswa yang tidak membawa } \\
\text { alat yang telah ditugaskan } \\
\text { 3. } 70 \% \text { siswa berani mencoba } \\
\text { melakukan percobaan tanpa ragu-ragu } \\
\text { 4. Tiap-tiap kelompok telah dapat } \\
\text { membagi tugas dengan baik pada } \\
\text { masing-masing anggota, meskipun ada } \\
\text { beberapa kelompok yang belum } \\
\text { melakukannya } \\
\text { 5. Sebagian siswa cukup teliti dan rajin }\end{array}$ & $\begin{array}{l}\text { 1. } 180 \% \text { of students are able to use } \\
\text { tools well such as thermometers, } \\
\text { litmus and universal indicators } \\
\text { 2. There are no students who do not } \\
\text { carry the equipment that has been } \\
\text { assigned } \\
\text { 3. } 70 \% \text { of students dare to try to } \\
\text { experiment without hesitation } \\
\text { 4. Each group has been able to divide } \\
\text { the tasks well with each member, } \\
\text { although there are some groups that } \\
\text { have not done it } \\
\text { 5. Some students are quite thorough }\end{array}$ \\
\hline
\end{tabular}

Received May $05^{\text {th }} 2020$, Revision June $07^{\text {th }} 2020$, Accepted for publication June $18^{\text {th }} 2020$.

Copyright $(2020$ Published by FKIP - Unpatti, ISSN 2721-3110 


\begin{tabular}{|c|c|c|c|}
\hline & $\begin{array}{l}\text { because in } 1 \text { group only } 2 \text { or } 3 \text { students } \\
\text { have their own awareness to make } \\
\text { observations on the object of research }\end{array}$ & $\begin{array}{l}\text { dalam melakukan pengamatan pada } \\
\text { obyek penelitian } \\
\text { 6. Siswa kurang terampil dalam } \\
\text { membuat hipotesis dan analisa data }\end{array}$ & $\begin{array}{l}\text { and diligent in observing the } \\
\text { research object } \\
\text { 6. Students are less skilled in making } \\
\text { hypotheses and analyzing data }\end{array}$ \\
\hline $\begin{array}{l}\text { RPP } 3 \\
\text { (The cause of } \\
\text { global warming } \\
\text { and its impact on } \\
\text { the ecosystem) }\end{array}$ & $\begin{array}{l}\text { 1. Some groups have not yet completed } \\
\text { their report } \\
\text { 2. 2. Most students are less skilled in } \\
\text { preparing reports. Among others } \\
\text { making problems, making hypotheses, } \\
\text { analyzing data and making conclusions. } \\
\text { 3. Students lack the courage to submit } \\
\text { reports to their friends verbally } \\
\text { 4. 50\% of students are less active in class } \\
\text { discussions }\end{array}$ & $\begin{array}{l}\text { 1. Some groups have not yet completed } \\
\text { their report } \\
\text { 2. Most students are less skilled in } \\
\text { preparing reports. Among others } \\
\text { making problems, making hypotheses, } \\
\text { analyzing data and making conclusions. } \\
\text { 3. Students lack the courage to submit } \\
\text { reports to their friends verbally } \\
\text { 4. 50\% of students are less active in class } \\
\text { discussions }\end{array}$ & $\begin{array}{l}\text { 1. All groups have completed the } \\
\text { report } \\
\text { 2. 2Students can make reports } \\
\text { according to the report } \\
\text { systematically well and present in } \\
\text { writing quite well } \\
\text { 3. Almost all group representatives } \\
\text { dare to submit their reports withou } \\
\text { being appointed by the teacher } \\
\text { 4. } 60 \% \text { of students dare to ask the } \\
\text { teacher and actively answer } \\
\text { questions. }\end{array}$ \\
\hline
\end{tabular}

Received May $05^{\text {th }} 2020$, Revision June $07^{\text {th }} 2020$, Accepted for publication June $18^{\text {th }} 2020$.

Copyright $\odot 2020$ Published by FKIP - Unpatti, ISSN 2721-3110 
Table 2. Percentage of Student Scientific Work Skills Assessment in Each Trial Class

\section{First Class}

Second Class

Third Class

\section{Scientific Work Skills}

Skor1 (\%) Skor $2(\%)$ Skor $3(\%)$

\%) Skor $4(\%)$ Skor

1Skor 2Skor 3Skor

(\%)

(\%)

(\%)

(\%)

Skor

(\%)

$(\%)$

(\%)

(\%)

\section{Make observations}

Formulate the problem

Merumuskan hipotesis

$0 \quad 68,4$

68,4
42,1

57,9

52,6

Designing experiments

Carry out experiments

63,2

36,9

Analyze the results of experiments 0

Make conclusions

18,4

0

Prepare a report

55,3

31,6
0
31,6
0
2,6
34,2
36,8
0

0
0
0
0
0
0
0
0

$0 \quad 35$

35
77,5
75

77,5
75

15,8
36,8

60,5

0

0
12,5

75
77,5

47,4

63,2

0

30

42,5

65

44,7

0

0

0

Communicating results

research

0

39,5

60,5

0

0

0

57,5

$42,5 \quad 0$

0

51,4

48,6

Table 4. Average Student Learning Outcomes

\begin{tabular}{|l|l|}
\hline \multicolumn{1}{|c|}{ Class } & Average learning outcomes \\
\hline First Class & 7,06 \\
\hline Second Class & 7,46 \\
\hline Third Class & 8,32 \\
\hline
\end{tabular}

Received May $05^{\text {th }} 2020$, Revision June $07^{\text {th }} 2020$, Accepted for publication June $18^{\text {th }} 2020$.

Copyright () 2020 Published by FKIP - Unpatti, ISSN 2721-3110

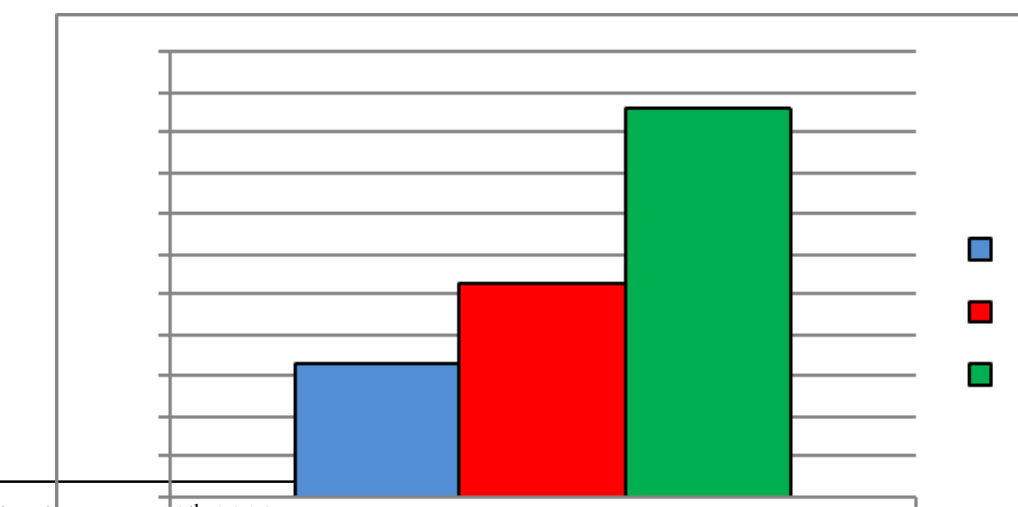

